\title{
CULTIVATION OF LETTUCE FERTILIZED WITH CONTROLLED- RELEASE NITROGEN FERTILIZER AND UREA
}

\author{
CULTIVO DE ALFACE ADUBADA COM FERTILIZANTE NITROGENADO DE \\ LIBERAÇÃO LENTA E UREIA
}

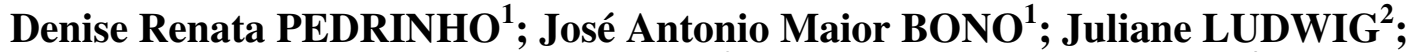 Vinicius Romeiro MARTINEZ ${ }^{3}$; Marcus Rodrigo de FARIA ${ }^{4}$}

1. Professor, University Anhanguera - Uniderp, Campus Agrárias, Campo Grande, MS, Brasil. bono@ uniderp.edu.br; 2. Professor, Federal University the South Border, Cerro Largo, RS, Brasil; 3. Student of University Anhanguera - Uniderp, Maracaju, MS, Brasil; 4. Master's student in Production and Agribusiness Management University Anhanguera - Uniderp, Campo Grande, MS, Brasil.

\begin{abstract}
Lettuce demands high levels of nitrogen, which appears in the soil in forms that present a complex dynamic, making it difficult to apply nitrogen-based fertilizers. One way to improve the efficiency of nitrogen absorption is to use controlled-release nitrogen fertilizers, which aim to maintain nitrogen in forms that are less susceptible to loss. The objective of this study was to evaluate the effect of two sources of $\mathrm{N}$ (urea and coated urea - slow-release N) in two management systems (fertilizer only at planting and fertilizer at planting and as a dressing) in the cultivation of American lettuce, cultivar Gloriosa, in an Entisols (Quartzipsamments), in the county of Campo Grande, Mato Grosso do Sul state (MS), Brazil. The experimental design used was randomized blocks in a 2 x 2 factorial scheme ( 2 sources of $\mathrm{N}$ and 2 systems for application of $\mathrm{N}$ ) and eight repetitions. The use of protected (coated) urea on the American lettuce crop did not lead to increased productivity in comparison with urea applied only at planting. On the other hand, the use of urea at planting and as a dressing presented higher productivity than the coated urea source.
\end{abstract}

KEYWORDS: Lactuca sativa L. Coated urea. Nitrogen.

\section{INTRODUCTION}

Lettuce (Lactuca sativa L.) is the most important leafy vegetable in Brazil (COSTA; SALA, 2005; FILGUEIRA, 2008). This species presents a good response to nitrogen-based fertilizer, with effects on production including increased plant size and improved appearance (KATAYAMA, 1993; SANTOS et al., 2001).

During lettuce cultivation, nitrogen $(\mathrm{N})$ is the second most extracted chemical element (BENINNI et al., 2005). In general, the nitrogenbased fertilization recommended for this crop is about 100 to $150 \mathrm{~kg} \mathrm{ha}^{-1}$ of $\mathrm{N}$ and 40 to $60 \mathrm{t} \mathrm{ha}^{-1}$ of cattle manure (RIBEIRO et al., 1999), with this divided into up to four applications, which substantially increases operating costs (LEZANA; CARRASCO, 2002).

LOPES et al., (2009) emphasize that the choice of nitrogen source and the application method may be determining factors for the efficient use of this nutrient. Increased efficiency in the use of nitrogen fertilizers has important economic and environmental implications. Nitrogen is the nutrient that most interacts with the environment, due to the numerous reactions that take place in the soil, whose activity is affected by temperature and humidity (FIXEN, 2010), being easily lost by leaching, volatility and denitrification in the soil-plant system (LEZANA; CARRASCO, 2002).
The efficiency of nitrogen can be increased by using controlled-release nitrogen-based fertilizers, which aim to maintain the nitrogen in forms that are less subject to loss. Among controlled or slow-release fertilizers, there are low-solubility products and soluble fertilizers that are coated or encapsulated with low-soluble compounds (CANTARELLA; MARCELINO, 2008). These products are to supply the nutrient at rates similar to those at which the plants can absorb it, preventing the nitrogen from spending a long time in the environment, a situation in which it becomes subject to various losses (Hall, 2005). It is also fundamental to improve techniques that allow the quality and productivity of plant crops to be improved, mainly in terms of multiple applications of fertilizer, which demand high labor costs (FILGUEIRA, 2008).

The objective of this study was to evaluate the effect of two sources of $\mathrm{N}$ (urea and coated urea - slow-release $\mathrm{N}$ ) in two management systems (fertilizer only at planting and fertilizer at planting + as a dressing) in the cultivation of American lettuce, cultivar Gloriosa, in an orthic quartzarenic neosol soil, in Campo Grande, MS, Brazil.

\section{MATERIAL AND METHODS}

The experiment was carried out in the region of Campo Grande, from May to July of 2011, in soil classified as orthic quartzarenic neosol 
(Quartz Sand), geographical coordinates of latitude $20^{\circ} 26^{\prime} 21^{\prime \prime}$ south and longitude 54 $32^{\prime} 27^{\prime \prime}$. The physical and chemical characteristics of the soil were as follows: $\mathrm{pH}$ in water 6.25 ; (P) $104 \mathrm{mg} \mathrm{dm}^{-3}$; $\left(\mathrm{K}^{+}\right) 30 \mathrm{mg} \mathrm{dm}^{-3} ;\left(\mathrm{Ca}^{+2}\right) 3.5 \mathrm{cmol}_{+} \mathrm{dm}^{-3} ;\left(\mathrm{Mg}^{+2}\right) 1.2$ $\mathrm{cmol}_{+} \mathrm{dm}^{-3} ;\left(\mathrm{H}^{+}\right) 1.4 \mathrm{cmol}_{+} \mathrm{dm}^{-3}$, organic matter (OM) $24.5 \mathrm{~g} \mathrm{~kg}^{-1}$, cation exchange capacity (CTC) $6.18 \mathrm{cmol}_{+} \mathrm{dm}^{-3}$, base saturation (V) $77 \%$, clay 115 $\mathrm{g} \mathrm{kg}^{-1}$, silt $30 \mathrm{~g} \mathrm{~kg}^{-1}$ and total sand $855 \mathrm{~g} \mathrm{~kg}^{-1}$ for methods in Embrapa (2009).

The seedlings were produced in a greenhouse, using pelletized seeds of American lettuce cultivar Gloriosa sown in an expanded polystyrene tray with 128 cells, previously filled with commercial substrate. For irrigation, $1000 \mathrm{~mL}$ of water per tray was used each day, distributed in 2 irrigations of $500 \mathrm{~mL}$ each.

The soil in the experimental area was corrected with dolomitic limestone $(\mathrm{PRNT}=110 \%)$ in a quantity of $3,500 \mathrm{~kg} \mathrm{ha}^{-1}$ applied by sprinkling and incorporated in the soil at a depth of $20 \mathrm{~cm}$ using a row-making tiller, $1 \mathrm{~m}$ wide, 30 days before transplanting the seedlings. To avoid contamination of nitrogen sources among the treatments, experimental plots $\left(1 \mathrm{~m}^{2}\right)$ were built individually.
For organic fertilization, $30 \mathrm{t} \mathrm{ha}^{-1}$ of cattle manure was applied 15 days before the seedlings were transplanted. Each experimental plot was $1 \mathrm{~m}^{2}$.

Transplant of seedlings took place 30 days after sowing, spaced at $25 \times 25 \mathrm{~cm}$, totaling 16 plants per plot. The used area was composed of the four central plants of each plot. The experimental design was randomized blocs in a $2 \times 2$ factorial scheme ( 2 sources of $\mathrm{N}$ and 2 application systems for $\mathrm{N}$ ) and eight repetitions. The sources of $\mathrm{N}$ were: urea $(45 \% \mathrm{~N})$ and urea coated in a starch chain (slow-release $32 \% \mathrm{~N}$ ) and the two systems of $\mathrm{N}$ application were fertilizer only at planting and fertilizer at planting + as a dressing $(10,20$ and 30 days after transplant).

A basic fertilization (Table 1) with $\mathrm{P}_{2} \mathrm{O}_{5}$ $\left(200 \mathrm{~kg} \mathrm{ha}^{-1}\right)$ and $\mathrm{K}_{2} \mathrm{O}\left(60 \mathrm{~kg} \mathrm{ha}^{-1}\right)$ was chosen in accordance with the interpretation of values found in soil analysis, for all treatments. The $\mathrm{P}$ was applied all in planting and the $\mathrm{K}$ applied in planting and dressing $(20 \%$ in the planting, 20\%, 30\% and $30 \%$ respectively 1 st, 2 nd and $3 \mathrm{rd}$ dressing, held to 15,30 and 40 days after the transplant), according to Ribeiro et al., (1999).

Table 1. Doses of fertilizers used in each treatment in culture of american lettuce cv. Gloriosa. Campo Grande, MS, 2011.

\begin{tabular}{|c|c|c|c|c|c|c|}
\hline \multicolumn{2}{|c|}{ Treatments } & \multirow{3}{*}{$\begin{array}{l}\text { Ntotal } \\
\left(\mathrm{g} \mathrm{m}^{2}\right)\end{array}$} & \multirow{3}{*}{$\begin{array}{l}\text { Planting } \\
\left(\mathrm{g} \mathrm{m}^{2}\right)^{*}\end{array}$} & \multirow{2}{*}{\multicolumn{3}{|c|}{$\begin{array}{c}\text { dressing } \\
\text { days after the transplant }\end{array}$}} \\
\hline \multirow{2}{*}{ Management } & \multirow{2}{*}{ Source } & & & & & \\
\hline & & & & 10 & 20 & 30 \\
\hline $\begin{array}{l}\text { Planting and } \\
\text { dressing }\end{array}$ & Urea & 15 & $\begin{array}{c}3 \mathrm{~g} \mathrm{~N}+20 \mathrm{~g} \\
\mathrm{P}_{2} \mathrm{O}_{5}+15 \mathrm{~g} \\
\mathrm{~K}_{2} \mathrm{O}\end{array}$ & $\begin{array}{c}3 \mathrm{~g} \mathrm{~N}+15 \mathrm{~g} \\
\mathrm{~K}_{2} \mathrm{O}\end{array}$ & $\begin{array}{l}4,5 \mathrm{~g} \mathrm{~N}+ \\
15 \mathrm{~g} \mathrm{~K}_{2} \mathrm{O}\end{array}$ & $\begin{array}{l}4,5 \mathrm{~g} \mathrm{~N}^{+} \\
15 \mathrm{~g} \mathrm{~K}_{2} \mathrm{O}\end{array}$ \\
\hline dressing & Urea & 15 & $\begin{array}{c}15 \mathrm{~g} \mathrm{~N}+20 \mathrm{~g} \\
\mathrm{P}_{2} \mathrm{O}_{5}+15 \mathrm{~g} \\
\mathrm{~K}_{2} \mathrm{O}\end{array}$ & $15 \mathrm{~g} \mathrm{~K}_{2} \mathrm{O}$ & $15 \mathrm{~g} \mathrm{~K}_{2} \mathrm{O}$ & $15 \mathrm{~g} \mathrm{~K}_{2} \mathrm{O}$ \\
\hline $\begin{array}{l}\text { Planting and } \\
\text { dressing }\end{array}$ & $\begin{array}{l}\text { Coated } \\
\text { Urea }\end{array}$ & 15 & $\begin{array}{c}3 \mathrm{~g} \mathrm{~N}+20 \mathrm{~g} \\
\mathrm{P}_{2} \mathrm{O}_{5}+15 \mathrm{~g} \\
\mathrm{~K}_{2} \mathrm{O}\end{array}$ & $\begin{array}{c}3 \mathrm{~g} \mathrm{~N}+15 \mathrm{~g} \\
\mathrm{~K}_{2} \mathrm{O}\end{array}$ & $\begin{array}{l}4,5 \mathrm{~g} \mathrm{~N}+ \\
15 \mathrm{~g} \mathrm{~K}_{2} \mathrm{O}\end{array}$ & $\begin{array}{l}4,5 \mathrm{~g} \mathrm{~N}^{+} \\
15 \mathrm{~g} \mathrm{~K}_{2} \mathrm{O}\end{array}$ \\
\hline dressing & $\begin{array}{l}\text { Coated } \\
\text { Urea }\end{array}$ & 15 & $\begin{array}{c}15 \mathrm{~g} \mathrm{~N}+20 \mathrm{~g} \\
\mathrm{P}_{2} \mathrm{O}_{5}+15 \mathrm{~g} \\
\mathrm{~K}_{2} \mathrm{O}\end{array}$ & $15 \mathrm{~g} \mathrm{~K}_{2} \mathrm{O}$ & $15 \mathrm{~g} \mathrm{~K}_{2} \mathrm{O}$ & $15 \mathrm{~g} \mathrm{~K}_{2} \mathrm{O}$ \\
\hline
\end{tabular}

At 48 days after transplant the lettuce was collected and evaluated. For this, the plants were cut at soil level and weighed, on a precision scale, to determine the fresh mass. The diameter of the stem was measured in four places, with the help of a digital pachymeter. After this, the plants were put, individually, in paper bags and taken to the drying oven with forced air circulation at $\pm 65^{\circ} \mathrm{C}$ until they reached constant weight, to obtain dry matter.

To analyze $\mathrm{N}$ in the leaves, the dry plants were ground in a Willy mill with a stainless steel sieve of 30 meshes per inch $(0.30 \mathrm{~mm})$. The leaf $\mathrm{N}$ was determined by digestion acid sulfuric method 
and quantified in the extract by the Kjeldhal method in accordance with Embrapa (2011).

The data were submitted to analysis of variance and to the means test using PROC GLM and PROC CORR for correlation analysis with procedures in the SAS program (SAS, 1993).

\section{RESULTS AND DISCUSSION}

When the application method for nitrogenbased fertilizers was evaluated, there was a significant effect for the aerial fresh matter and dry matter variables, as well as for the stem diameter. For the stem diameter variable, there was an effect of the interaction between $\mathrm{N}$ source used and the application method, with this interaction therefore being doubled and the effect of the application method being observed within each source (Table 2).

With regard to the accumulation of fresh and dry matter by the plants, it was seen that both were significantly higher when fertilizer was applied at planting and as a cover dressing (Table 3 ).

Table 2. Summary of the analysis of variance with mean square and the significance probability $(\operatorname{Pr}>\mathrm{F})$ for fresh and dry matter of the aerial part, diameter of the stem and leaf nitrogen content on culture of American lettuce cv. Gloriosa. Campo Grande, MS, 2011.

\begin{tabular}{|c|c|c|c|c|c|c|c|c|c|}
\hline \multirow{2}{*}{$\begin{array}{l}\text { Causes of } \\
\text { variation }\end{array}$} & \multirow{2}{*}{ GF } & \multicolumn{2}{|c|}{$\begin{array}{l}\text { Fresh matter of aerial } \\
\text { part }\end{array}$} & \multicolumn{2}{|c|}{$\begin{array}{c}\text { Dry matter of } \\
\text { aerial part }\end{array}$} & \multicolumn{2}{|c|}{ Stem diameter } & \multicolumn{2}{|c|}{$\begin{array}{c}\text { Leaf nitrogen } \\
\text { content }\end{array}$} \\
\hline & & $\begin{array}{l}\text { Medium } \\
\text { Square }\end{array}$ & $\operatorname{Pr}>\mathrm{F}$ & $\begin{array}{l}\text { Medium } \\
\text { Square }\end{array}$ & $\operatorname{Pr}>\mathrm{F}$ & $\begin{array}{l}\text { Medium } \\
\text { Square }\end{array}$ & $\operatorname{Pr}>\mathrm{F}$ & $\begin{array}{l}\text { Medium } \\
\text { Square }\end{array}$ & $\operatorname{Pr}>\mathrm{F}$ \\
\hline Block & 7 & 35831,389 & $0,9744^{\mathrm{ns}}$ & 114,392 & $0,764^{\mathrm{ns}}$ & 27,667 & $0,1761^{\mathrm{ns}}$ & 159,26 & $0,838^{\mathrm{ns}}$ \\
\hline Source & 1 & 5760,938 & $0,6190^{\mathrm{ns}}$ & 2,800 & $0,7523^{\mathrm{ns}}$ & 13,390 & $0,0277^{*}$ & 84,30 & $0,197^{\mathrm{ns}}$ \\
\hline Way & 1 & 123641,213 & $0,0293 *$ & 213,729 & $0,0119 *$ & 41,632 & $0,0004 * *$ & 119,04 & $0,128^{\mathrm{ns}}$ \\
\hline Source*Way & 1 & 44352,845 & $0,1759^{\mathrm{ns}}$ & 32,805 & $0,2926^{\mathrm{ns}}$ & 20,320 & $0,0083 * *$ & 32,684 & $0,4158^{\mathrm{ns}}$ \\
\hline \multicolumn{10}{|c|}{ Unfolding of the interaction Soucre* Way to stem diameter } \\
\hline Coated Urea & 1 & & & & & 1,896 & $0,3843^{\mathrm{ns}}$ & & \\
\hline Uréia & 1 & & & & & 60,063 & $25,08 * *$ & & \\
\hline Means & & \multicolumn{2}{|c|}{678,952} & \multicolumn{2}{|c|}{29,39} & \multicolumn{2}{|c|}{17,78} & \multicolumn{2}{|c|}{50,71} \\
\hline $\mathrm{CV} \%$ & & \multicolumn{2}{|c|}{22,14} & \multicolumn{2}{|c|}{18,05} & \multicolumn{2}{|c|}{8,7} & \multicolumn{2}{|c|}{13,6} \\
\hline
\end{tabular}

Table 3. Means of fresh and dry matter from aerial part in $\left(\mathrm{g} \mathrm{pl}^{-1}\right)$ for two sources and forms of application of nitrogen-based fertilizer in the American lettuce cv. Gloriosa. Campo Grande, MS, 2011.

\begin{tabular}{lcccc}
\hline \multirow{2}{*}{ Source } & \multicolumn{2}{c}{ Fresh matter of aerial part } & \multicolumn{2}{c}{ Dry matter of aerial part } \\
\cline { 2 - 5 } & Planting & Planting and dressing & Planting & $\begin{array}{c}\text { Planting and } \\
\text { dressing }\end{array}$ \\
\hline Coated Urea & $640.61 \mathrm{Aa}$ & $690.47 \mathrm{Ba}$ & $28.13 \mathrm{Aa}$ & $31.27 \mathrm{Aa}$ \\
Urea & $592.98 \mathrm{Bb}$ & $791.76 \mathrm{Aa}$ & $25.50 \mathrm{Aa}$ & $32.70 \mathrm{Aa}$ \\
Mean & $616.80 \mathrm{~b}$ & $741.12 \mathrm{a}$ & $26.82 \mathrm{~b}$ & $31.99 \mathrm{a}$ \\
\hline
\end{tabular}

Means followed by different letters differ by $\mathrm{F}$ test at 5\% probability. Lowercase in line and uppercase in column

The lettuce crop remained in the field for 48 days, a period considered enough to show the difference between the application methods for the nitrogen fertilizer, because nitrogen presents a complex dynamic and does not leave direct residual effects of the fertilizer applications, making its management difficult, as reported by Raij (2011). Studies carried out by Resende et al., (2010) and Silva et al., (2008), with nitrogen fertilizer on
American lettuce, found doses of $\mathrm{N}$ varying from 89.6 to $257.14 \mathrm{~kg} \mathrm{ha}^{-1}$.

The use of coated urea was not enough to prevent losses of $\mathrm{N}$, probably because of the daily irrigation of the crop. These data were in contrast to those of Ratke et al., (2011), who found increased productivity with the use of slow release fertilizers on rocket salad. 
Urea and coated urea present $\mathrm{N}$ in the starch form, which is transformed in the soil into the ammonium form $\left(\mathrm{NH}_{4}{ }^{+}\right)$, by the action of an enzyme, known as urease. In this transformation process, ammonia is formed $\left(\mathrm{NH}_{3}\right)$, an intermediate product, which is a gas. When this ammonia occurs on the surface of the soil, the product can be lost into the atmosphere, representing losses of $\mathrm{N}$ ( $\mathrm{BONO}$ et al 2006). Considering the increase in production of fresh and dry matter seen between applying $\mathrm{N}$ at planting and applying it at planting and as a dressing, it is confirmed that uncoated urea provided increments of $198.78 \mathrm{~g}$ and $7.2 \mathrm{~g}$ respectively for the fresh and dry matter of the aerial part, while coated urea furnished increments of $49.86 \mathrm{~g}$ and $3.14 \mathrm{~g}$, respectively, for the fresh and dry matter (Table 3 ).

As the lettuce crop cycle is very fast, the urea protection process was supposed to delay the action of urease on urea, reducing the demand for $\mathrm{N}$, and being reflected in smaller amounts of coated urea.
As regards the stem diameter, when fertilizer was applied entirely at planting no effect was observed between the two sources used. On the other hand, when fertilizer was applied at planting and as a dressing, the urea produced a better result than the coated urea (Table 4). These data contradict those of Mendonça et al., (2007) who found benefits in slow-release $\mathrm{N}$ for the formation of passion-fruit seedlings. The lower efficiency of the management fertilization only at planting may be due to conditions such as soil humidity, $\mathrm{pH}$ and temperature which, when appropriate, transformation from ammoniac nitrogen, arising from starch or ammoniac fertilizers, into nitrate within a period of 15 to 30 days (CANTARELLA and MONTEZANO, 2010); with nitrate predominating in the soil, there is likely to be more leaching. In its ammoniac form, $\left(\mathrm{NH}_{4}{ }^{+}\right) \mathrm{N}$ undergoes transformations into its nitric form $\left(\mathrm{NO}_{3}\right)$, predisposing $\mathrm{N}$ to leaching (CANTARELLA et al., 2008). These losses by leaching may be significant, varying from 30 to $70 \%$ of the $\mathrm{N}$ applied to the soil (SOUSA; LOBATO, 2002).

Table 4. Means of stem diameter $\left(\mathrm{mm} \mathrm{pl}^{-1}\right)$ for two sources and forms of application of nitrogen-based fertilizer in the American lettuce cv. Gloriosa. Campo Grande, MS, 2011.

\begin{tabular}{lcc}
\hline Source & Planting & Planting and dressing \\
\hline Coated urea & $16,79 \mathrm{Aa}$ & $17,49 \mathrm{Aa}$ \\
Urea & $16,49 \mathrm{Ab}$ & $20,36 \mathrm{Aa}$ \\
\hline
\end{tabular}

Means followed by different letters differ by $\mathrm{F}$ test at $5 \%$ probability. Lowercase in line and uppercase in column

This type of nitrogen-based fertilizer management shows again that the use of conventional sources in lettuce crops needs to involve application of the nutrient at periods that make it possible for plants to absorb it. This is shown by the fact that both sources (Table 5), independent of their management system, showed the same concentration of $\mathrm{N}$ in the dry matter of the aerial part. The mean values for $\mathrm{N}$ in the aerial part were between 46.0 and $55.0 \mathrm{~g} \mathrm{~kg}^{-1}$, within the range established by Embrapa (2009), which is 30 to $50 \mathrm{~g}$ $\mathrm{kg}^{-1}$ and by Martinez et al., (1999) at $40 \mathrm{~g} \mathrm{~kg}^{-1}$. The form of application at planting and with dressing produced the highest $\mathrm{N}$ content in the aerial part of lettuces, indicating greater efficiency in the use of nitrogen applied in the soil.

Table 5. Means of leaf nitrogen content $\left(\mathrm{g} \mathrm{kg}^{-1}\right)$ for two sources and forms of application of nitrogen-based fertilizer in the American lettuce cv. Gloriosa. Campo Grande, MS, 2011.

\begin{tabular}{lcc}
\hline Source & Planting & Planting and dressing \\
\hline Coated urea & $48,17 \mathrm{Aa}$ & $50,01 \mathrm{Aa}$ \\
Urea & $49,39 \mathrm{Ab}$ & $55,27 \mathrm{Aa}$ \\
\hline
\end{tabular}

Means followed by different letters differ by $\mathrm{F}$ test at $5 \%$ probability. Lowercase in line and uppercase in column

In this study it was seen that the stem diameter had a significant (positive) linear correlation with fresh and dry matter of the aerial part of plants (Figure 1). Considering the angular coefficients of the adjusted linear models, it was confirmed that the fresh matter presented higher values than the dry matter, showing a better correlation with stem diameter. This variable can be associated as a development indicator for the aerial part and stem is normally considered an aerial part of the plant. Santi el al 2013 working with cultivars of American lettuce, found that in larger diameter cultivars of stem, also occurred as many total sheets and commercial. Being a simple and easily executed measurement, it could be adopted as a parameter for evaluations of lettuce crops. 
These data demonstrate that the production of lettuce in soils of low fertility is possible, since the nitrogen fertilizer management is performed according to the characteristics of the fertilizer being used.

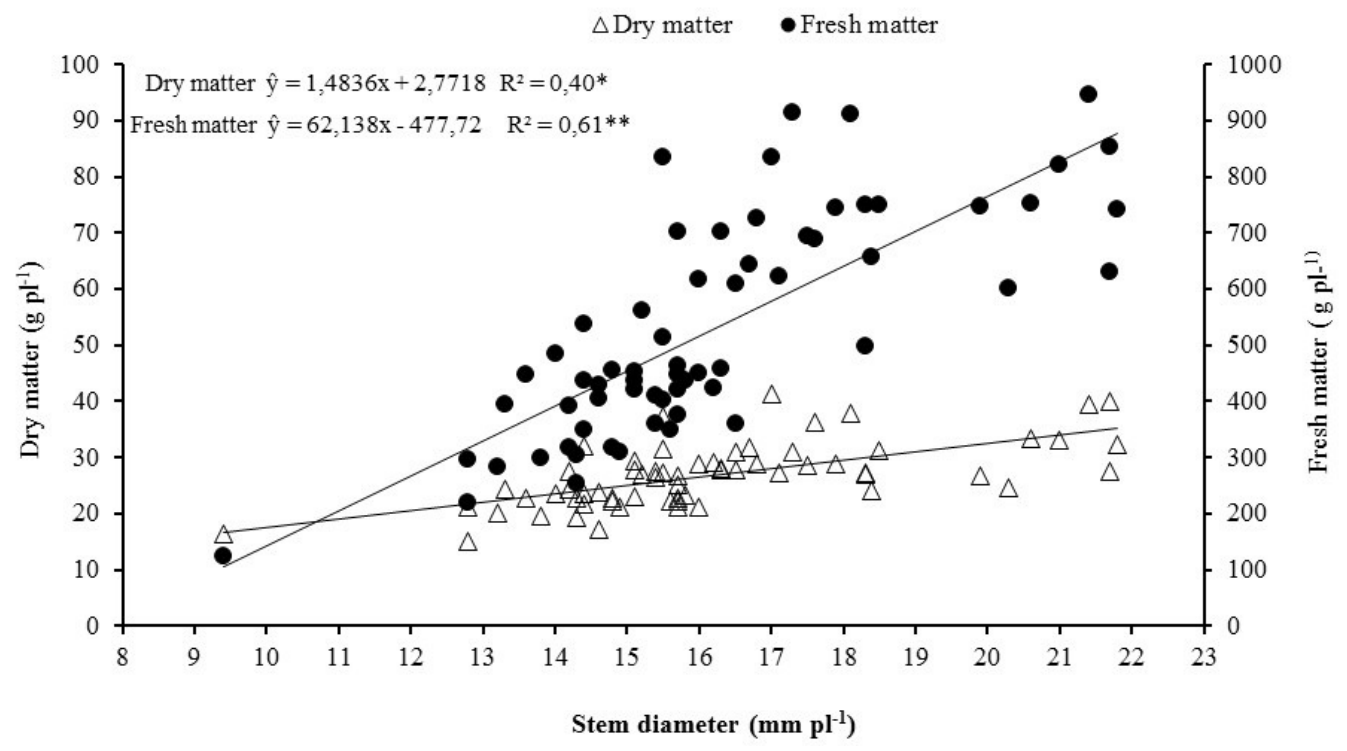

Figure 1. Simple and Pearson correlation between stem diameter and fresh matter and dry matter of the aerial part of American lettuce plant cv. Gloriosa, submitted to two sources and forms of application of nitrogen-based fertilizer. Campo Grande, MS, 2011.

* Pearson correlation coefficient significant at 5\% probability; **Pearson correlation coefficient significant at $1 \%$ probability.

\section{CONCLUSIONS}

The use of coated urea fertilization in culture of lettuce can all be used in planting, without subdivision in soils of low fertility.
The best management for the nitrogen fertilizer based on urea in lettuce is application on planting and in planting and dressing in low fertility soils.

RESUMO: A alface é uma hortaliça exigente em nitrogênio, cujas formas no solo apresentam uma dinâmica complexa, dificultando as adubações nitrogenadas. Uma maneira de melhorar a eficiência de absorção do nitrogênio é o uso de fertilizantes nitrogenados de liberação controlada, que visam manter o nitrogênio em formas menos sujeitas a perdas. O objetivo desse estudo foi avaliar o efeito de duas fontes de $\mathrm{N}$ (ureia e ureia encapsulada - $\mathrm{N}$ de liberação lenta) em dois tipos de manejo (adubação somente no plantio e adubação de plantio + cobertura) no cultivo da alface americana cultivar Gloriosa em um solo Neossolo Quartzarênico Órtico, no município de Campo Grande MS. O arranjo experimental utilizado foi de blocos ao acaso em esquema fatorial 2 × 2 ( 2 fontes de $\mathrm{N}$ e 2 manejos de aplicação de $\mathrm{N}$ ) e oito repetições. $\mathrm{O}$ uso de ureia protegida (encapsulada) na cultura da alface americana, não proporcionou incremento de produtividade quando comparada a ureia manejada apenas no plantio. Por outro lado, o uso de ureia manejada no plantio e em cobertura, apresentou produtividade superior a fonte de ureia protegida..

PALAVRAS-CHAVE: Lactuca sativa L. Ureia protegida. Nitrogênio.

\section{REFERENCES}

BENINNI, E.; TAKAHASH, H. W.; NEVES, C. S. J. concentração e acúmulo de macronutrientes em alface cultivada em sistemas hidropônico e convencional. Semina: Ciências Agrárias, Londrina, v. 25, n. 3 p. 26 : 273-282. 2005. 
BONO, J. A. M.; SETTI, J. C. de A.; SPEKKEN, S. S. P. O nitrogênio protegido como alternativa de fertilizante para o uso no plantio da cultura do algodão. Ensaios e Ciência, Campo Grande, v. 10, p. 39 - 45, 2006.

CANTARELLA, H; MARCELINO, R. Fontes alternativas de nitrogênio para a cultura do milho. Informações Agronômicas, Piracicaba, Potafos, n. 122, p. 12-14. 2008.

CANTARELLA, H.; MONTEZANO, Z. F. Nitrogênio e Enxofre, In: PROCHONOW, L. I.; CASARIN, V.; STIPP, S. R (eds). Boas Práticas para o uso eficiente de fertilizantes. v. 2. Piracicaba: INPI. 2010. p.1-65.

CANTARELLA, H.; TRIVELIN, P. C. O.; CONTIN, T. L. M.; DIAS, F. L. F.; ROSSETTO, R.; MARCELINO, R.; COIMBRA, R. B.; QUAGGIO, J. A. Ammonia volatilization from urease inhibitor-treated urea applied to sugarcane trash blankets. Scientia Agricola, Piracicaba, v. 65: n. 4, p. 397-401. 2008. http://dx.doi.org/10.1590/S0103-90162008000400011

COSTA, C. P.; SALA, F. C. A evolução da alfacicultura brasileira. Horticultura Brasileira, Brasília, v. 21, n. 2, p. 820-824. 2005.

EMBRAPA, Empresa Brasileira de Pesquisa Agropecuária. Manual de Análise Química de solos plantas e fertilizantes $2^{\mathrm{a}}$ ed. revista. Brasília: (Embrapa Solos - Documentos 132). 2011, 230p.

EMBRAPA, Empresa Brasileira de Pesquisa Agropecuária. Manual de Análise Química de solos plantas e fertilizantes. Brasília: Embrapa Comunicação para Transferência de Tecnologia. 2009, 627p.

FILGUEIRA, F. A. R. Novo manual de olericultura: agrotecnologia moderna na produção e comercialização de hortaliças. Viçosa: UFV. 2008. 421p.

FIXEN, P. E. The four rights within a global fertilizer best management practices framework. In: PROCHNOW LI; CASARIN V; STIPP SR (eds). Boas práticas para uso eficiente de fertilizantes. Piracicaba: International Plant Nutrition Institute. 2010. p. 1-22.

HALL, W. Benefits of enhanced-efficiency fertilizers for the environment. In: INTERNATIONAL WORKSHOP ON ENHANCED-EFFICIENCY FERTILIZERS, Proceedings... Alemanha: International Fertilizer Industry Association, 2005. 1 CD-ROM.

KATAYAMA, M. Nutrição e adubação de alface, chicória e almeirão. In: FERREIRA, M. E.; CASTELLANE, P. D.; CRUZ, M. C. P. (eds). Nutrição e adubação de hortaliças. Piracicaba: POTAFOS. 1993. p. 141-148.

LEZANA JR; CARRASCO I. 2002. 3,4-dimetilpirazol fosfato (dmpp): el nuevo inhibidor de la nitrificación para fertilizantes - Experiencias en sistemas de fertirrigación. Vida Rural: n. 22, p. 49-50. 2002.

LOPES, R. A.; BUZETTI, S.; TEIXEIRA FILHO, M. C.; GARCIA, C. M. P. Efeito de doses e épocas de aplicação de nitrogênio em dois cultivares de arroz de terras altas irrigado sob plantio direto em solo de cerrado. In: CONGRESSO BRASILEIRO DE CIÊNCIA DO SOLO, 23. Anais... Fortaleza: SBCS, 2009. 1 CD-ROM.

MARTINEZ, H. E. P.; CARVALHO, J. G. de; SOUZA, R. B. do. Diagnose foliar. In: RIBEIRO, A. C.; GUIMARÃES, P. T. G.; ALVARES, V. C. (eds). Recomendação para o uso de corretivos e fertilizantes em Minas Gerais: $5^{\text {a }}$ aproximação. Viçosa: UFV. 1999. p. 143-167.

MENDONÇA, V.; TOSTA, M. S.; MACHADO, J. R.; GOULART JUNIOR, S. A. R.; TOST , J. S.; BISCARO, G. A. Fertilizante de liberação lenta na formação de mudas de maracujazeiro 'amarelo'. Ciência e Agrotecnologia, Lavras, v. 31, n. 2, p. 344-348. 2007.

RAIJ, B. V. Fertilidade do solo e manejo de nutriente. Piracicaba: IPNI. 2011.420p. 
RATKE, R. F.; VERGINASSI, A.; BASTO, D. C.; MORGADO, H. S.; SOUZA, M. R. F.; FERNANDES, E. P. Production and levels of foliar nitrogen in rocket salad fertilized with controlled-release nitrogen fertilizers and urea. Horticultura Brasileira, Brasília, v. 29, n. 2, p. 246-249. 2011. http://dx.doi.org/10.1590/S010205362011000200020

RESENDE, G. M.; ALVARENGA, M. A. R.; YURI, J. E.; SOUZA, R. Doses de nitrogênio e molibdênio no rendimento e teor de micronutrientes em alface americana. Horticultura Brasileira v. 28, n. 3, p. 266-270. 2010. http://dx.doi.org/10.1590/S0102-05362010000300004

RIBEIRO, A. C.; GUIMARÃES, P. T. G; ALVARES. V. C. Recomendação para o uso de corretivos e fertilizantes em Minas Gerais: $5^{\text {a }}$ aproximação. Viçosa: UFV. 1999. 359p.

SANTI, A.; SCARAMIZZA, W. L. M. P.; NEUHAUS, A. DALLACORT, R.; KRAUSE, W.; TIEPPO, R C. Desempenho agronômico de alface americana fertilizada com torta de filtro em ambiente protegido, Horticultura Brasileira, Brasília, v. 31, n. 2, p. 338-346, 2013. http://dx.doi.org/10.1590/S010205362013000200027

SANTOS, R. H. S.; SILVA, F.; CASALI, V. W. D.; CONDE, A. R. Efeito residual da adubação com composto orgânico sobre o crescimento e produção de alface. Pesquisa Agropecuária Brasileira, v. 36, n. 11, p. 13951398. 2001. http://dx.doi.org/10.1590/S0100-204X2001001100010

SAS System Analysis Statistics, User’s Guide, Version 6.4 ed., Cary. NC: SAS Institute Inc. 1993, 840p.

SILVA, P. A. M.; PEREIRA, G. M.; REIS, R. P.; LIMA, L. A.; TAVEIRA, J. H. S. Função de resposta de alface americana aos níveis de água e adubação nitrogenada. Ciência e Agrotecnologia, Lavras, v. 32: n. 4, p. 1266-1271. 2008.

SOUSA, D. M. G. de; LOBATO, E. Cerrado: correção de solo e adubação. $1^{\text {a }}$ ed. Planaltina: Embrapa Cerrados. 2002. 416p. 